\title{
高圧ローラゲートの振動に関する実験的研究
}

\section{AN EXPERIMENTAL STUDY ON VIBRATION PHENOMENA OF THE NEW FIXED WHEEL GATE UNDER THE HIGH HEAD DAM}

\author{
荻原国宏*・菅原一昌**・白毛良男***.千葉幸憲**** \\ By Kunihiro OGIHARA, Kazumasa SUGAWARA, Yoshio SHIRAGE and Yukinori CHIBA
}

\begin{abstract}
A new type of fixed wheel gate has been developed for regurating gate of high head dam. Through a series of experimental and theoretical analysis, it has been clarified that the new type of gate was applicable in real gates and was proved stable in dynamic behavior against vibrations due to the fluctuating water pressure without any divergences. The stability has been evaluated both by model tests and numerical analysis. The structure has been analysed by a model subjected to the distributed loads which were measured on a model of new type gate through laboratory tests. The static loads are also measured and analysed same as dynamic loads. The results about the responces of gate vibration system by dynamic loads which are measured in model tests, show good coincidence with the measured data in field gate. Therefor the method as shown here gives good solutions for estimating the forced vibration phenomena of gate system.
\end{abstract}

Keyword: gate vibration, fixed wheel gate, forced vibration

\section{1. まえがき}

ローラゲートは扉体の受ける水圧力を，ローラを介し て戸当り金物により支持する構造であるため, 水路側壁 に戸溝を必要とし，場合によってはこれが障害の原因と なることがある.

高水圧下で流量調節放流を行う場合，従来型ローラ ゲートでは扉体底部からの放流水脈が戸溝内またはその ごく近傍で大気中に放流されるので，圧力の解放に伴う 水脈の水平方向への抬散角が大きく $(60 \sim 80$ 度 $)$ なり， そのため高速エネルギーをもった水脈が戸溝内に突入し 上昇流となってローラに衝突して好ましくない振動を与 えるとか, キャビテーションを発生させるなど不具合な 点がある. したがって, 高圧調節放流用としてのローラ ゲートは, 下流に導水路を必要としないアーチダム用に 使われるにとどまっている.

新型ローラゲートは, 高圧調節放流用として下流側に

* 正会員 工博 東洋大学教授 工学部土木工学科 （干350 川越市鲸井中野台 2100）

** 正会員 日本鋼管（株）鋼構造営業部 （１１00 千代田区丸の内 1-1-2）

*** 日本鋼管 (株) 鋼構造建設部水門計画室長 ( ₹230 横㙃市鶴見区末広町 2-1)

**** 工修 日本鋼管（株）鋼構造建設部水門計画室主任部員 (同上)
導水路を必要とする設備に対してもローラゲートの設置 を可能とするために開発されたものであり，上記ローラ ゲートの久陥を除去したものである. 本ローラゲートに ついては, 参考文献 ${ }^{1), 2)}$ に実験・研究について報告して いる.

構造原理は Fig. 1 に示すように戸溝開口部上流端から 所定の距離（整流側壁長 l）だけ上流にゲートリップお よび水密機構を位置させた構造である．この場合，放流 水の水平拡散を大幅におさえることができ，水理特性も よく，あたかも戸溝がないように整流されて放流できる 構造である.

高圧ゲートの振動は放水時の水流の脈動による圧力変

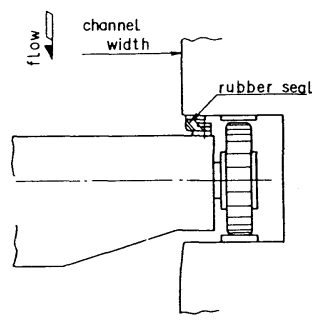

a. Conventional type

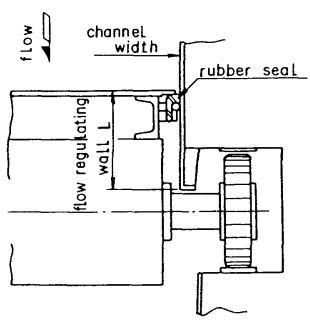

b. NDF type
Fig. 1 Cross sectional comparison of conventional and NDF fixed wheel gate. 
動によって惹起する．アーチダムに用いられている高圧 バーチカルゲートは, ゲート開度が小さいときはゲート 扉体のたわみ振動が主であり，ゲートが全開近くなると メーンローラ軌条の振動が卓越して固有振動数が小さく なる.アーチダム以外のダム高圧ゲートに用いられてい るラジアルゲートの振動数はゲートの開度に関係なくほ ぼ一定であり，脚柱の振動が大きく扉体の振動は微小で ある．脚柱の振動制御には構造または剛性をまして対処 している．実験により本ローラゲートは開度に関係なく 屝体のたわみ振動が主であるのでむしろラジアルゲート の扉体の振動に近いといえる.

本ローラゲートの振動に関し実験的に検討したので以 下にその概要を報告する。

なお，新型ローラゲートは Non-Dispersed Flow Roller Gate (非拡散流ローラゲート) と命名し, NDF ロー ラゲートとよんでいる.

\section{2. 実験装置および実験方法}

模型のゲートは上下可動できるようにし，放流管模型 とは独立した支持台に吊り下げた。 実験装置の関係より $1 / 14$ の幾何学的相似とした.

実験方法としては Fig. 2 に示すようにローラゲートの 模型扉体に所定の 4 か所（No.1 No.4）に圧力センサ （定格容量 $0.2 \mathrm{kgf} / \mathrm{cm}^{2}$, 非直線性 $1 \% \mathrm{FS}$ ) を取り付 け圧力変動を測定した.この圧力変動を実物に換算して, 実物大に想定されたゲートに作用させ応答解析を用い て,ゲートの振動を解析し検討した。

圧力変動值は, 増幅器を経てデータレコーダにその波 形を記録した。

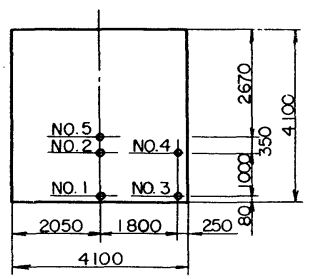

Fig. 2 Location of pressure sensors.

\section{3. 相 似 律}

模型実験は，模型で起こった現象から実物での現象を 推論しようとするものであるから, 両者の現象が幾何学 的に相似であるばかりでなく，力学的にも相似でなくて はならない.この種の実験では流れにおける諸量のうち， 重力の影響が支配的であると考えられるため, 模型と実 物との重力之慣性力の比を同一と考え，実物と模型との 間でフルード数を一致することにより両者の力学的相似
Table 1 Scale ratio.

\begin{tabular}{|l|c|c|c|}
\hline item & dimension & \multicolumn{2}{|c|}{ scale ratio } \\
\hline tength & $L$ & $n$ & $1: 14=0.0714$ \\
\hline velocity & $L T^{-1}$ & $n^{1 / 2}$ & $1: \sqrt{14}=0.2673$ \\
\hline discharge & $L^{3} T^{-1}$ & $n^{5 / 2}$ & $1: \sqrt{14^{5}}=1.3636 \times 10^{-3}$ \\
\hline pressure & $M L^{-1} T^{2}$ & $n$ & $1: 14=0.0714$ \\
\hline time & $T$ & $n^{1 / 2}$ & $1: \sqrt{14}=0.2673$ \\
\hline
\end{tabular}

が成り立つ.このフルードの法則に従い主な諸量の縮率 の関係は Table 1 のようである.

本実験の場合, 流れの乱れを主として受ける振動が主 体と考えられるので, 水理模型実験により扉体に作用す る変動圧の測定を目的とし, 扉体の弾性相似を満足させ る必要はないと考えられる. しかし，この相似律を用い ることにより, 水理模型実験では得られなかった放流時 の原形の扉体の振幅を計算することができる3).

条件として,

$$
\left(\frac{\rho \cdot g \cdot A \cdot L^{3}}{E I}\right)_{m}=\left(\frac{\rho \cdot g \cdot A \cdot L^{3}}{E I}\right)_{\rho}
$$

ここに,

$$
\begin{aligned}
\rho \cdot g \cdot A & : \text { 単位径間当たりの重量 } \\
L & : \text { ゲート径間 } \\
E I & : \text { 曲げ剛性 }
\end{aligned}
$$

である. 実物 $(p)$ と模型 $(m)$ を同一形状，同一比重 の材料で作ると, 弾性相似を満足する模型と実物とのヤ ング率 $E$ の比は,

$$
\frac{E_{m}}{E_{p}}=\frac{L_{m}}{L_{p}}=n
$$

となる．本実験では同一材料を用いており，模型の剛性 は，実物の $1 / n$ ，すなわち 14 倍の剛性を有しているこ とになる.これは模型の剛性が非常に大きく, 屝体を固 定とみなしてもよいと考えられる．したがって模型実験 で計測した圧力変動値は固定壁に作用する流体固有の圧 力変動と等しくなっているといえる.

なお，本報告書で取り扱う数値はすべて実物に換算し た值である。

\section{4. 圧力変動の測定結果}

実験によって，貯水池水位 WL $114 \mathrm{~m}$ および WL 125 $\mathrm{m}$ ，ゲート開度 $a=10 \%$ 90\%について,ゲートリー フ面の圧力変動を測定した.

圧力変動に関しては，高水頭・大開度になるに従って 変動値が大きくなる傾向を示し，同一条件ではゲート リップ面（No.1および 3 ）が大きく，ゲート中央部 (No.2 および 4) で小さい值となっている. 変動圧の 大きいWL $125 \mathrm{~m}$ 時点での波形の一部を Fig. 3 に示す. 図中の数値は実物に換算した值であり，模型の実測值は （）内に示している.

圧力変動の最大值は, WL $125 \mathrm{~m}$, ゲート開度 $90 \%$ の 


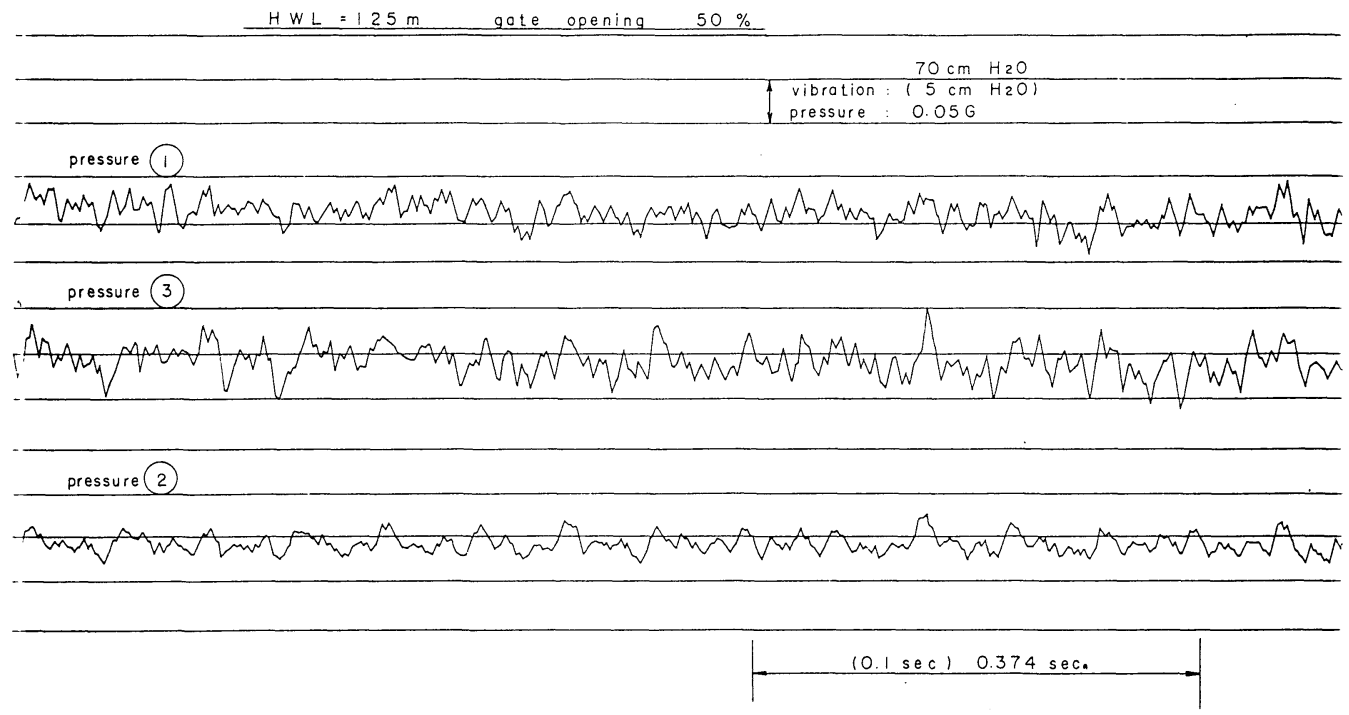

Fig. 3 Fluctuating pressure at the gate.

場合に発生しており,その值は $0.109 \mathrm{kgf} / \mathrm{cm}^{2}(10.69$ $\left.\mathrm{kN} / \mathrm{m}^{2}\right)$ であった.なお, No. 4 センサーは計測の際バ ランスがとれなかったので, 変動波形より割愛している.

\section{5. ゲートの固有振動解析}

圧力変動によるゲートの応答振動を求める前に, 実物 のゲートの固有振動を数値計算により調查した. 空気中 での固有振動, 片面接水での固有振動を有限要素法を用 いた 3 次元汎用構造解析プログラム4)を用いて計算し た.

$$
\begin{aligned}
& \text { 振動の一般式は } \\
& M \ddot{u}+C \dot{u}+K u=R(t) \\
& \text { 固有値は }
\end{aligned}
$$

$M \ddot{u}+K u=0$

であり, サブスペースイテレーション法により求めた. ただし, $M$ : 質量, $u$ : 変位, $C$ : 減衰定数, $K$ : ばね 定数, $R(t)$ : 外力である.

振動解析は Table 2 の 3 種類のゲート開度に対して 行った.

ケース 1 および 2 は水圧により全ローラが戸当り金物 に接しているモデルであり，ケース 3 は水圧が扉体の底 面にのみ作用し，扉体が反転しており，最下部のローラ と上部のフロントローラが戸当り金物に接しているモデ ルである.

各ケースとも, 空中振動と接水振動は同一の境界条件

Table 2 Vibration analysis conditions.

\begin{tabular}{|c|c|c|c|}
\hline Case condition & in air & in water & gate opening \\
\hline 1 & $1-A$ & $1-W$ & $10 \%$ \\
\hline 2 & $2-A$ & $2-W$ & $50 \%$ \\
\hline 3 & $3-A$ & $3-W$ & $90 \%$ \\
\hline
\end{tabular}

であり, 接水振動では扉体の上流側の水を付加質量とし て考慮している.

\section{（1）解析モデル}

新型ローラゲートは多数の平板および骨組部材で構成 されているので, シェル要素・骨組要素・境界要素とし てモデル化を行った.

骨組要素としての枌は，その中立軸を通る一本の直線 とみなすので，同一平面上にない骨組構造をモデル化す る場合, 要素間に比較的剛性の大きいダミ一の連結材 (三 次元骨組要素) を設け実物に近づけた.

Fig. 4 にゲートの略図を示す.

境界条件としてケース $1 \cdot 2$ すなわち $10 \%, 50 \%$ 開 度の場合には， $X$ 方向（屝体の左右方向）は片側 2 個 のサイドローラでばね支持, $Y$ 方向（扉体の上下方向） はシリンダーでばね支持, $Z$ 方向（扉体の前後方向） は片側 5 個のローラシャフトで支持，ケース 3 すなわち $90 \%$ 開度の場合には， $X$ 方向・ $Y$ 方向は上記之同様で あるが， $Z$ 方向のみ異なり最下部のローラシャフトで 支持し，上部はフロントローラでばね支持となる.

計算に用いられた断面性能は Table 3 のとおりであ る.

\section{（2）付加質量}

固有振動数を求めるために，（1）でモデル化した部 材以外の部材を付加質量として節点に作用させた．水中 振動の場合は付加水質量を求め節点に作用させた。

接水している構造物は, 流体の影響により固有振動数 が低下する．これは物体の表面に加わる流体力が付加水 質量として作用したためである. 振動解析を行う場合, この付加水質量の正確な算定が必要となる. 本来この種 


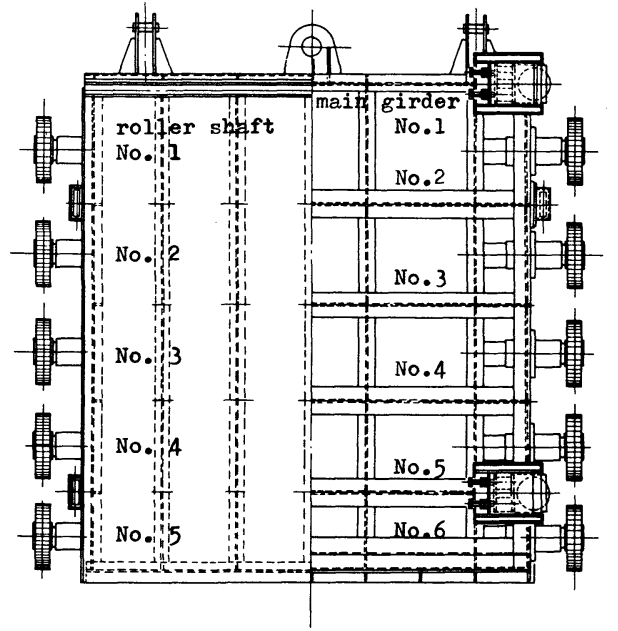

Fig. 4 Front view of gate.

の問題は流体と弾性体との連成振動となり, 厳密解を得 るのが相当困難である.たとえば船体の振動に関しても 簡易式を用いるのが実情であり, 本解析でもその手法に ならった。

付加水質量の算出方法は参考文献 ${ }^{5}$ による. 屝体に作 用する単位面積当たりの付加水質量は次のようになる.

$$
\begin{aligned}
m_{w} & =\rho_{w} \cdot l \cdot \xi \\
& =1.02 \times 10^{-6} \times 435 \times 0.454 \\
& =2.0152 \times 10^{-4} \mathrm{kgf} / \mathrm{cm}^{2}\left(1.9762 \times 10^{-2} \mathrm{kN} / \mathrm{m}^{2}\right)
\end{aligned}
$$

ただし， $\rho_{w}:$ 水の単位体積当たり質量

$l:$ 節線間距離 $\cdots \Gamma$ 側壁の影響が最も大きくな

\begin{tabular}{|c|c|c|c|c|c|}
\hline item & element & $A X \mathrm{~cm}^{2}$ & $1 x^{\mathrm{cm}^{4}}$ & $1 \mathrm{Ycm}^{4}$ & $12 \mathrm{~cm}^{4}$ \\
\hline skin plate & rectangular shell & & & & \\
\hline main girder (1) & 3 dimensional bar & 156.6 & 288.0 & 163863 & 1692 \\
\hline (2) & $\because$ & 238.8 & 492.6 & 262973 & 7823 \\
\hline (3) & 11 & 265.2 & 1584.6 & 274960 & 5613 \\
\hline (4) & $" 1$ & 181.2 & 313.8 & 174817 & 11487 \\
\hline side girder (5) & " & 156.6 & 288.0 & 163863 & 2892 \\
\hline diaphragm (6) & $" 1$ & 125.6 & 87.1 & 120120 & 1073 \\
\hline 17 & $" 1$ & 178.8 & 312.6 & 173992 & 1698 \\
\hline roller shaft (8) & $" 1$ & 452.4 & 32572 & 16286 & 16286 \\
\hline sub-beam (9) & $"$ & 37.66 & 7.745 & 4050 & 294 \\
\hline "110 & $"$ & 44.07 & 18.625 & 4180 & 306 \\
\hline connector (11) & $u$ & $4.0 \times 10^{4}$ & $2.0 \times 10^{6}$ & $2.0 \times 10^{6}$ & $2.0 \times 10^{6}$ \\
\hline (12) & $" 1$ & $6.0 \times 10^{4}$ & $3.0 \times 10^{6}$ & $3.0 \times 10^{6}$ & $3.0 \times 10^{6}$ \\
\hline cylinder & boundary & $\begin{array}{r}\text { case } 1 \\
2 \\
3 \\
\end{array}$ & $\begin{array}{r}k x=5612 \\
2098 \\
2458\end{array}$ & $\begin{array}{l}8 \mathrm{kgf} / \mathrm{cm} / 5 \\
30 " \\
32,\end{array}$ & $\begin{array}{lll}55043 \mathrm{kN} / \mathrm{m}) \\
20574 & \mathrm{n} & 1 \\
24107 & \mathrm{n} & 1 \\
\end{array}$ \\
\hline front roller (14) & $" 1$ & case & $k x=821$ & $.5 \mathrm{kgf} / \mathrm{km} / 8$ & $053.7 \mathrm{~N} / \mathrm{cm})$ \\
\hline side roller (15) & " & $\left.\begin{array}{ll}\text { case } & 1 \\
& 2 \\
3\end{array}\right\}$ & $\begin{array}{r}k x=2825 \\
1277\end{array}$ & $\begin{array}{c}5 \mathrm{~kg} / \mathrm{cm} \\
0 \mathrm{~N} / \mathrm{cml})\end{array}$ & \\
\hline
\end{tabular}
る 0 節モードの場合常に $l=b$ （ゲート扉
Table 3 Section dimensions.

AX : sectional area

IX: polarmoment of inertia

IY: geometrical moment of inertia

I Z . "

体高）とする」

$\xi$ : 接水条件 $C_{w} \cdot$ 防撓材 $C_{s}$. 開口 $C_{h}$ の有無 を考慮した付加水質量係数

$\xi=\xi_{1} \times C_{w} \times C_{s} \times C_{h}$

$=0.454 \times 1 \times 1 \times 1=0.454$

\section{(3) 固有振動数}

各ケースごとの空中および片面接水での固有振動数を 求め結果を Table 4 にまとめている. またそれぞれの モードをプロットしたが Fig. 5 にケース 2 の場合につい て示す.図中の点線で示しているのがメッシュ図であり,

\begin{tabular}{|c|c|c|}
\hline mode & in air & in water \\
\hline ist & 2.825 & 2.825 \\
\hline $2 n d$ & 3.472 & 3.472 \\
\hline $3 \mathrm{rd}$ & 7.375 & 7.374 \\
\hline $4 \mathrm{th}$ & 55.09 & 45.28 \\
\hline $5 \mathrm{th}$ & 84.41 & 46.48 \\
\hline
\end{tabular}

Table 4 Natural frequencies in air and water. case 1 (gate opening 10\%) $\mathrm{Hz}$

case 2 (gate opening $50 \%$ ) $\mathrm{Hz}$

\begin{tabular}{|c||c|c|}
\hline mode & in air & in water \\
\hline ist & 2.825 & 2.825 \\
\hline 2nd & 3.472 & 3.472 \\
\hline $3 \mathrm{rd}$ & 4.535 & 4.535 \\
\hline $4 \mathrm{th}$ & 55.06 & 47.13 \\
\hline sth & 8438 & 55.78 \\
\hline
\end{tabular}

\begin{tabular}{|c||c|c|}
\multicolumn{4}{|c|}{ case 3 (gate opening $90 \%$ ) $\mathrm{Hz}$} \\
\hline mode & in air & in water \\
\hline Ist & 2.819 & 2.819 \\
\hline $2 \mathrm{nd}$ & 3.469 & 3.469 \\
\hline $3 \mathrm{rd}$ & 4.785 & 4.783 \\
\hline $4 \mathrm{th}$ & 5.052 & 5.050 \\
\hline $5 \mathrm{th}$ & 15.73 & 15.72 \\
\hline $6 \mathrm{th}$ & 63.40 & 52.28 \\
\hline
\end{tabular}
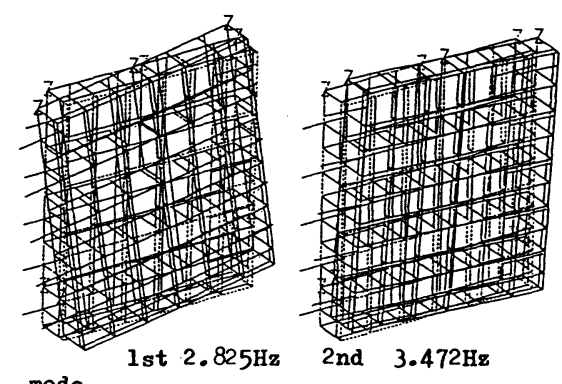

mode

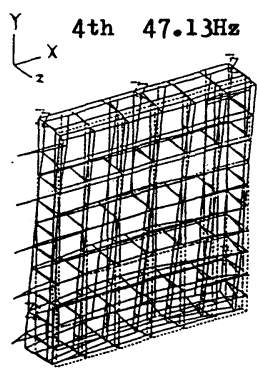

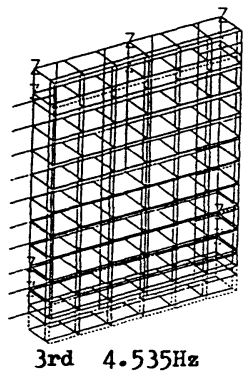

5 th $55.78 \mathrm{~Hz}$

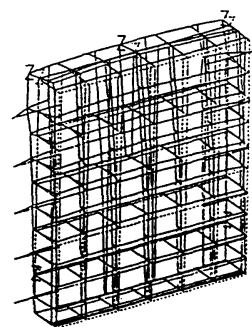

Fig. 5 Vibration mode in water. 
実線がモード図である.

ケース 1 および 2 の場合, $1 \sim 3$ 次モードが $X Y$ 平面 で剛体振動をしており, 片面接水の条件でも付加水質量 が作用せず空中での固有振動数と同じ值となっている. また, 4 次モ一ド以上が弾性体振動であり, 片面接水の 場合，付加水質量の影響により空中での 固有振動数より低下している. その低下 率はモードにより異なっている.ケース 3 の場合, 1 4 次モードが剛体振動を しており, 5 次モード以上が弾性体振動 である.ケース 3 は開度 $90 \%$ であり， 流体に接している部分が少なく付加水質 量の影響も小さい.

\section{6. ゲートの応答解析}

有限要素法による 3 次元汎用構造解析 プログラム4)を用いて応答解析を行い, ゲートの振動特性を調べた。応答解析は 直接積分法を用い，開度 $10 ， 50,90 \%$ (ケース 1，2，3）の3 ケースに対して 行った。

直接積分法はウィルソンシータ法を用 いており, 時増分 $\Delta T$ は 0.004 秒とし た.

溶接構造のゲートの減衰係数は普通 $0.03 \sim 0.05$ の值がとられるが，他の高 圧バーチカルローラゲートの実測值より 扉体の前後方向の減衰係数として $0.03^{6)}$ を採用した。

\section{（1）入力波形}

応答解析に用いる外力は 4. で得られ た実測値を大型計算機用に作成し，実物 の圧力に変換後, ゲート開度を考慮して スキンプレート前面の各節点に作用させ た。

王力変動はダムの水位とゲート開度が 同じ場合でもスキンプレートのおのおの の位置でやや異なった值を示している が，振動波形もやや同じような形を示し ており, 結果的に大きな違いが生じない と考え，また，計算を簡単にするために 次の値を採用した。

1）水位は変動幅の大きい HWL= $125 \mathrm{~m}$ の值

2) 同一開度の場合, 変動幅の大きい No. 1 センサの值を代表值とした.

入力波形をケース 2 について Fig. 6 に
示す.

\section{（2）節点変 位}

各節点の変位を縦軸に時間を横軸にしてプロットした ものの一部, ケース 2 の場合について Fig. 7 に示す. 節 点としてスキンプレート面の中央部の 8 点をとり,

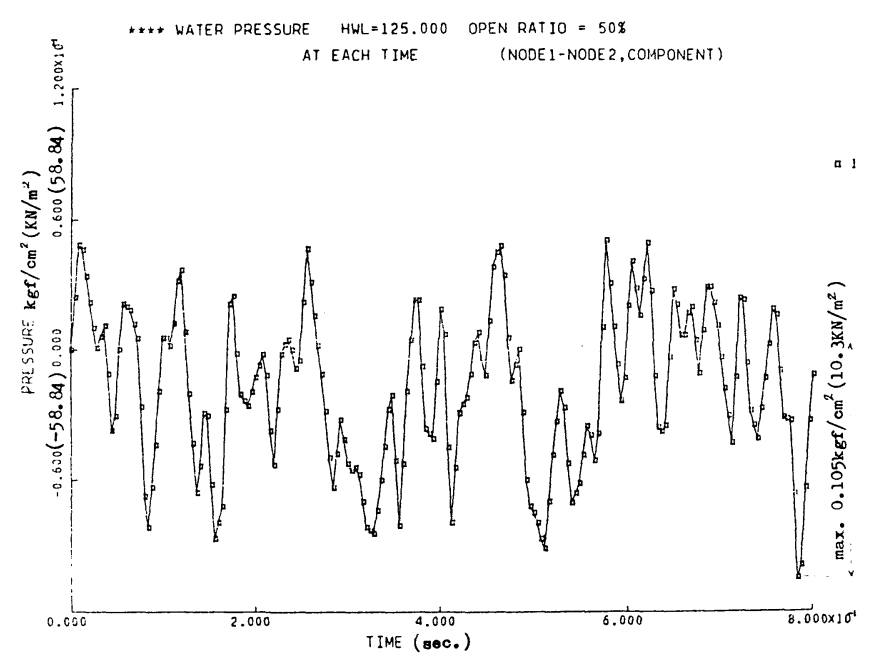

Fig. 6 Input wave (case 2).
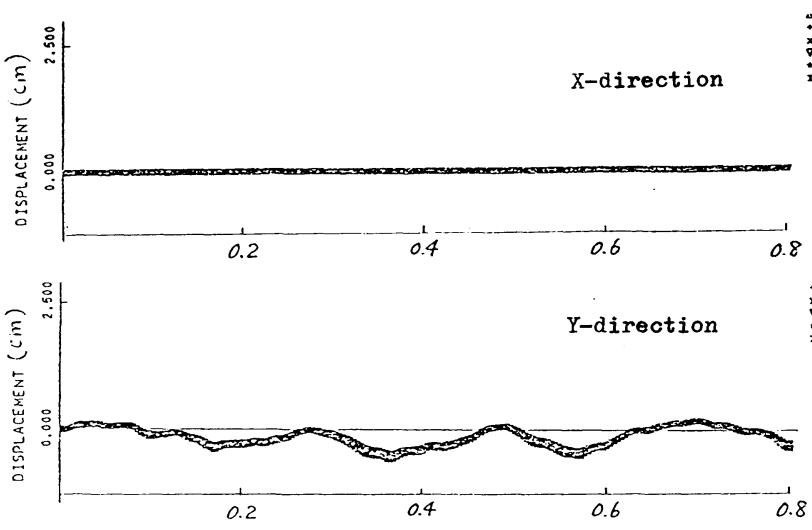

* * NDF ROLLER Gate (DYNAMIC RESPONSE) CASE 2 (HNL = 125.0 OPEN RATIO=50Z)

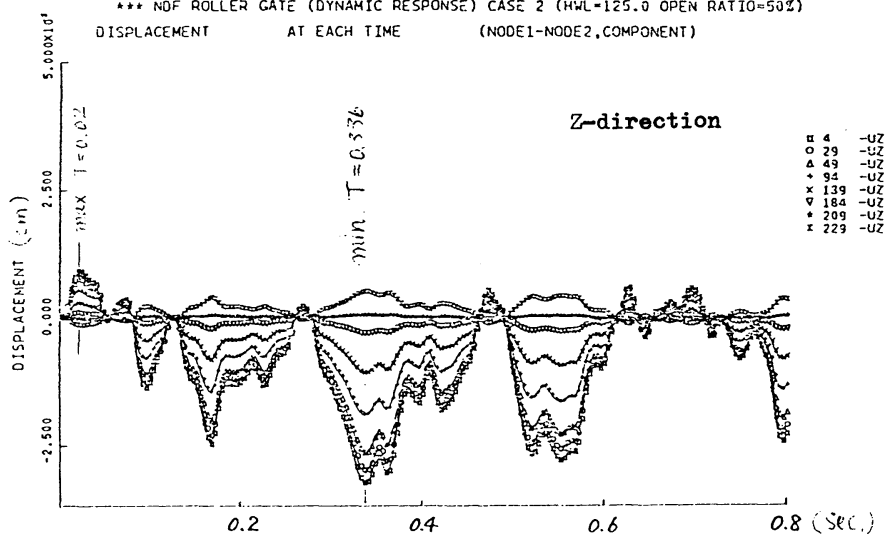

Fig. 7 Dynamic response displacement (gate opening $50 \%$ ). 
$X \cdot Y \cdot Z$ 方向の変位を示している.

$X$ 方向には変位せず， $Y$ 方向・ $Z$ 方向にはほぼ同じ 波形で変動しており振幅は $Z$ 方向が $Y$ 方向のほぼ 10 倍である，いずれの場合でも振幅は発散せず, 圧力変動 を受けて不規則振動をしている. $Z$ 方向の変位につい て着目すると，ケース 1（開度 $10 \%$ ）の場合は屝体が 同一方向に変位しているが，ケース2（開度 $50 \%$ ）の 場合はNo. 1 主析が他の析と逆方向に変位し, ケース 3

（開度 $90 \%$ ）になるとNo.1〜4主桁がNo. 5, 6 主栴 と逆方向に変位しており, ゲート開度による節点変位の 相違がわかる. Fgi. 7 中, 十変位は上流側, 一変位は下 流側の方向を示す.

最大振幅はケース 2 で発生しており, Fig. 8 に示す. 最大值は $\delta_{\max }=0.032 \mathrm{~mm}$ であり，これを模型の振偪に 換算すると, 幾何縮尺 $n$, 弾性相似による剛性比 $n^{\prime}$ と すれば

$$
\delta_{m}=\delta_{\max } \times n \times n^{\prime}=0.032 \times(1 / 14)^{2}=0.000163 \mathrm{~mm}
$$

となり工学上振幅 0 と考えられる. この解析結果から前 述の 3 項において模型の扉体を固定壁とみなしたことが 妥当であったと考えられる.

扉体全体の振動モードを把握するため に，ある時刻における節点の変位をプ ロットしたが，ここでは Fig. 8 にスキン プレート面のリップ位置が $Z$ 方向に対 して最大となる時刻の振動モードを示し た. 最大および最小になる時刻は Fig. 7 の節点時刻歴に示している.

Fig. 8 の中で点線で示しているのが メッシュ図であり, 実線がモード図であ る. 圧力変動による振動の振幅は非常に 小さいので, 振幅のスケールを 10000 倍し, 図中に示した.

応答解析より得られた振動モードは数 值計算よりの固有振動モードとほぼ相似 している. 変位・振動数もオーダ一的に 合っている.

\section{（3）節点加速度}

節点変位と同様に各節点の加速度の時 間履歴をプロットしたものの一部, ケー ス 2 について Fig. 9 に示す.

力と加速度との間には $F=m \cdot a$ の関 係があり, 加速度の波形は外力波形とよ く一致している.

加速度の最大值はケース 1 の $10 \%$ 開 度で発生しており, その值は $28 \mathrm{~cm} / \mathrm{s}^{2}$ であるが, 部材力の最大值はケース 2 の $50 \%$ 開度で発生している.これは, ゲー

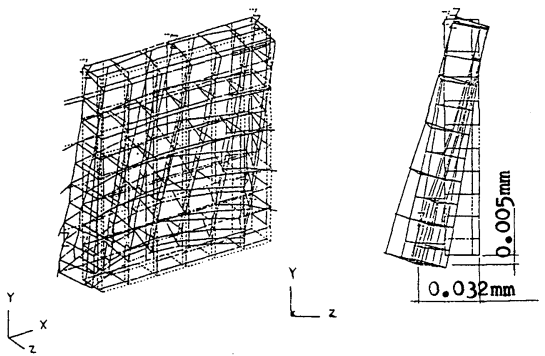

Fig. 8 Dynamic response mode at $0.336 \mathrm{sec}$. elapsed time (case 2-HWL $125 \mathrm{~m}$ gate opening $50 \%$ ).

卜開度が大きくなると変動圧が増加するが受生面積が減 少し, 結局, 作用する外力が小さくなったためと考えら れる.

\section{（4）部材応力}

応答解析の結果得られた部材力の時間履歴をプロット してみたが, 部材力の波形は節点変位の波形とよく一致 した。

この部材力より主析の各応力を求めた結果を最大応力

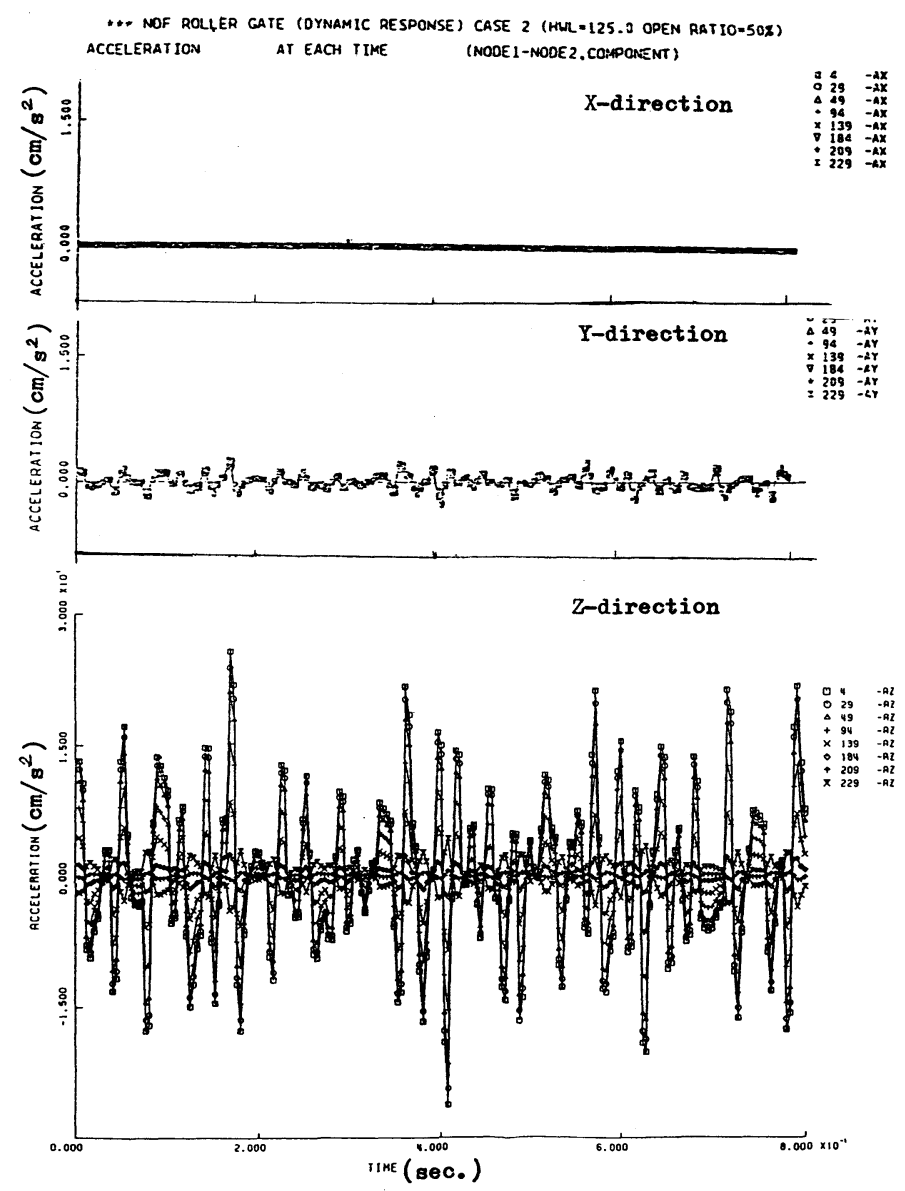

Fig. 9 Dynamic response acceleration (case 2). 
Table 5 Forces and stresses in main girders (case 2).

\begin{tabular}{|c|c|c|c|c|c|c|c|c|}
\hline \multirow{2}{*}{$\begin{array}{l}\text { main } \\
\text { girder }\end{array}$} & \multirow{2}{*}{$\begin{array}{c}F I t f \\
\text { normal } \\
\text { force } \\
(K N)\end{array}$} & \multirow{2}{*}{$\begin{array}{c}F 2 \text { tf } \\
\text { shearing } \\
\text { force } \\
(\mathrm{KN})\end{array}$} & \multirow{2}{*}{$\begin{array}{c}F 3 \quad t f \\
\text { shearing } \\
\text { force } \\
(\mathrm{KN})\end{array}$} & \multirow{2}{*}{$\begin{array}{c}M 1 \mathrm{t} \cdot \mathrm{m} \\
\text { torgue } \\
(\mathrm{KN} \cdot \mathrm{m})\end{array}$} & \multirow{2}{*}{$\begin{array}{l}\mathrm{M} 2 \mathrm{tf} \cdot \mathrm{m} \\
\text { bending } \\
\text { moment } \\
(\mathrm{KN} \cdot \mathrm{m})\end{array}$} & \multirow{2}{*}{$\begin{array}{l}\mathrm{M} 3 \mathrm{t} f \cdot \mathrm{m} \\
\text { bending } \\
\text { moment } \\
(\mathrm{KN} \cdot \mathrm{m})\end{array}$} & \multicolumn{2}{|c|}{ stress $\mathrm{kgf} / \mathrm{cm}^{2}\left(\mathrm{KN} / \mathrm{m}^{2}\right)$} \\
\hline & & & & & & & $\sigma N=\frac{F_{1}}{A}$ & $\sigma b=\frac{M 2}{Z}$ \\
\hline 1 & $\begin{array}{c}0.053 \\
(0.520)\end{array}$ & $\begin{array}{l}0.001 \\
(0.010)\end{array}$ & $\begin{array}{c}0.034 \\
(0.3331\end{array}$ & 0.0 & $\begin{array}{r}0.04404 \\
(0.43188)\end{array}$ & $\begin{array}{l}0.00051 \\
0.005001\end{array}$ & $\begin{array}{l}0.3 \\
1291\end{array}$ & $\begin{array}{l}11 \\
11081\end{array}$ \\
\hline 2 & $\begin{array}{r}0.140 \\
11.3731\end{array}$ & $\begin{array}{c}0.003 \\
(0.029)\end{array}$ & $\begin{array}{c}0.082 \\
10.8041 \\
\end{array}$ & 0.0 & $\begin{array}{r}0.08835 \\
(0.86642)\end{array}$ & $\begin{array}{l}0.00437 \\
(0.04286)\end{array}$ & $\begin{array}{c}0.6 \\
(59) \\
\end{array}$ & $\begin{array}{c}1.3 \\
(127)\end{array}$ \\
\hline 3 & $\begin{array}{c}0.449 \\
(4.403)\end{array}$ & $\begin{array}{l}0.018 \\
(0.177)\end{array}$ & $\begin{array}{c}0.013 \\
(0.127)\end{array}$ & 0.0 & $\begin{array}{l}0.17874 \\
(1.75284)\end{array}$ & $\begin{array}{l}0.00170 \\
(0.01667)\end{array}$ & $\begin{array}{l}1.7 \\
(167)\end{array}$ & $\begin{array}{r}2.5 \\
(245) \\
\end{array}$ \\
\hline 4 & $\begin{array}{l}0.771 \\
17.5611\end{array}$ & $\begin{array}{r}0.020 \\
10.1961 \\
\end{array}$ & $\begin{array}{r}0.134 \\
11.3141\end{array}$ & 0.0 & $\begin{array}{r}0.33899 \\
13.32436\end{array}$ & $\begin{array}{l}0.00066 \\
(0.00647)\end{array}$ & $\begin{array}{l}2.9 \\
(284)\end{array}$ & $\begin{array}{l}4.9 \\
14811\end{array}$ \\
\hline 5 & $\begin{array}{c}0.982 \\
(9630)\end{array}$ & $\begin{array}{r}0.005 \\
100491\end{array}$ & $\begin{array}{l}0.133 \\
(1.304)\end{array}$ & 0.0 & $\begin{array}{r}0.44380 \\
(4.35219 \\
\end{array}$ & $\begin{array}{l}0.00502 \\
(0.04923)\end{array}$ & $\begin{array}{c}3.7 \\
(363)\end{array}$ & $\begin{array}{l}6.5 \\
(637)\end{array}$ \\
\hline 6 & $\begin{array}{r}0.779 \\
(7.639) \\
\end{array}$ & $\begin{array}{c}0.010 \\
(0.098) \\
\end{array}$ & $\begin{array}{r}0.096 \\
10.9411\end{array}$ & 0.0 & $\begin{array}{r}0.34232 \\
(3.35701\end{array}$ & $\begin{array}{l}0.00792 \\
10.07767)\end{array}$ & $\begin{array}{r}4.3 \\
14221 \\
\end{array}$ & $\begin{array}{l}7.8 \\
(765)\end{array}$ \\
\hline
\end{tabular}

Table 6 Forces and stresses in roller shafts.

\begin{tabular}{|c|c|c|c|}
\hline \multirow[b]{3}{*}{ shatt } & \multicolumn{3}{|c|}{ case $2 \quad(50 \%)$} \\
\hline & \multicolumn{2}{|c|}{ force } & \multirow{2}{*}{$\begin{array}{l}\text { stress } \mathrm{kg} / \mathrm{cm}^{2} \\
\left(\mathrm{KN} / \mathrm{m}^{2}\right) \\
\sigma_{\mathrm{b}}=\frac{\mathrm{M} 2}{\mathrm{Z}}\end{array}$} \\
\hline & $\begin{array}{c}\text { F3 tf } \\
\text { shearing } \\
\text { force } \\
\text { (KN) }\end{array}$ & $\begin{array}{l}\mathrm{M} 2 \mathrm{t} f \cdot \mathrm{m} \\
\text { bending } \\
\text { moment } \\
(\mathrm{KN} \cdot \mathrm{m})\end{array}$ & \\
\hline 1 & $\begin{array}{c}0.065 \\
(0.637)\end{array}$ & $\begin{array}{c}0.02633 \\
(0.25821)\end{array}$ & $\begin{array}{l}2.0 \\
1196)\end{array}$ \\
\hline 2 & $\begin{array}{c}0.206 \\
120201\end{array}$ & $\begin{array}{c}0.08343 \\
(0.81817)\end{array}$ & $\begin{array}{c}6.1 \\
(598)\end{array}$ \\
\hline 3 & $\begin{array}{c}0.465 \\
(4.560)\end{array}$ & $\begin{array}{c}0.18833 \\
(1.84689)\end{array}$ & $\begin{array}{c}13.9 \\
(1363)\end{array}$ \\
\hline 4 & $\begin{array}{l}0.736 \\
(7.218)\end{array}$ & $\begin{array}{c}0.29808 \\
(2.92317) \\
\end{array}$ & $\begin{array}{r}22.0 \\
(2157)\end{array}$ \\
\hline 5 & $\begin{array}{c}1.087 \\
(10.660)\end{array}$ & \begin{tabular}{|c}
0.44024 \\
$(4.31728)$
\end{tabular} & $\begin{array}{l}32.4 \\
(3177)\end{array}$ \\
\hline
\end{tabular}

の発生するケース 2 について Table 5 に示した。同様に ローラシャフトの部材力よりの応力が Table 6 である. いずれの場合でも圧力変動によって生ずる応力は小さい 值となっている. なお，部材力の関係を Fig. 10 に示す.

\section{7. 静的解析}

変動圧によって生ずる応力がゲートに対して有害か否 かを検討するため，前述と同じプログラムを用い静的解 析を行った. モデルは固有值解析に用いたものと同一で ある。

荷重は扉体が全閉状態で設計水圧を受けるものとして スキンプレートに作用させた。

主析の部材力の解析結果を, 最大応力の発生する No. 3 主析と最下主桁 No. 6 について, Table 7 に示し た. 手計算による簡略計算によって得られた応力と比較 すると, せん断応力ではほぼ同じ値であり, 曲げモーメ ント等による直応力では簡易計算より 16 - 38 \% 小さい 値である。これは簡略計算時に無視したスキンプレー ト・補助析・ダイヤフラムの影響を有限要素法では考慮 していることに起因していると考えられる.

同様にローラシャフトの部材力を Table 8 に示した.

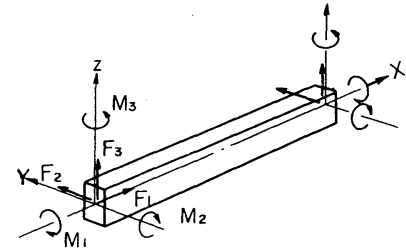

Fig.10 Coodinate system of 3-dimensional bar element

簡略計算值と比較すると土 $6 \%$ 以内にあり，ほぼ同じ值 となっている．有限要素法で上部および下部のローラ反 力が大きくなっているが，これは側部桁のオーバーハン グによるたわみの影響によるものである。

この静的解析結果をもとに振動による応力を検討す る. 検討位置としては最下部の主析中央部と最下部の ローラシャフト部であるが，主析は静的・動的の応力が 小さいので, 両応力が比較的大きい No. 5 ローラシャフ トで検討する.

ローラシャフトの断面性能は, 軸径 $d=240 \mathrm{~mm}$, 断 面係数 $Z=1357 \mathrm{~cm}^{3}$, 材質 S $45 \mathrm{C}$, 降伏点 $\sigma_{y}=35 \mathrm{kgf} /$ $\mathrm{mm}^{2}\left(343 \mathrm{MN} / \mathrm{m}^{2}\right)$, 引張強さ $\sigma_{B}=58 \mathrm{kgf} / \mathrm{mm}^{2}(569 \mathrm{MN} /$ $\mathrm{m}^{2}$ ) である.

許容応力としては次による.

Table 8 Shearing forces (static).

\begin{tabular}{|c|c|c|}
\hline shaft & FEM & $\begin{array}{l}\text { conventional } \\
\text { calculation }\end{array}$ \\
\hline 1 & $\begin{array}{r}41.962 \\
(411.51)\end{array}$ & $\begin{array}{c}39.538 \\
(387.74)\end{array}$ \\
\hline 2 & $\begin{array}{l}38.651 \\
379.04 \\
\end{array}$ & $\begin{array}{l}39.164 \\
884.08\end{array}$ \\
\hline 3 & $\begin{array}{l}36.986 \\
(362.71) \\
\end{array}$ & $\begin{array}{l}38.975 \\
(382.21)\end{array}$ \\
\hline 4 & $\begin{array}{r}37.334 \\
(366.12) \\
\end{array}$ & $\begin{array}{c}39.053 \\
(382.98)\end{array}$ \\
\hline 5 & $\begin{array}{r}41.270 \\
1404.72 \\
\end{array}$ & $\begin{array}{l}39.473 \\
(387.10)\end{array}$ \\
\hline sum & $\begin{array}{r}196.203 \\
(1924.09) \\
\end{array}$ & $\begin{array}{r}196.203 \\
(1924.09) \\
\end{array}$ \\
\hline
\end{tabular}

Table 7 Forces and stresses in main girders (static).

\begin{tabular}{|c|c|c|c|c|c|c|c|c|}
\hline \multirow[b]{2}{*}{$\begin{array}{l}\text { main } \\
\text { girder }\end{array}$} & \multirow{2}{*}{$\begin{array}{l}F \mid t f(K N) \\
\text { normal } \\
\text { force }\end{array}$} & \multirow{2}{*}{$\begin{array}{l}\text { F2 tf(KN) } \\
\text { shearing } \\
\text { force }\end{array}$} & \multirow{2}{*}{$\begin{array}{l}\text { F3 tf(KN) } \\
\text { shearing } \\
\text { force }\end{array}$} & \multirow{2}{*}{$\begin{array}{l}\text { MItf.m } \\
\text { torque }\end{array}$} & \multirow{2}{*}{$\begin{array}{l}\text { M2 tf } \mathrm{m} \\
\text { bending } \\
\text { moment } \\
\mathrm{KN} \text { m }\end{array}$} & \multirow{2}{*}{$\begin{array}{l}\text { M3 tfim } \\
\text { bending } \\
\text { moment } \\
(\mathrm{KN}, \mathrm{m})\end{array}$} & \multicolumn{2}{|c|}{ stress $\mathrm{kg} f / \mathrm{cm}^{2}\left(\mathrm{KN} / \mathrm{m}^{2}\right)$} \\
\hline & & & & & & & $v=\frac{F l}{A}$ & 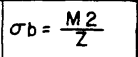 \\
\hline 3 & & & & & & & & \\
\hline 6 & 7 & & 04.251 & $\begin{array}{l}0.00687 \\
(0.06737)\end{array}$ & 133 & $\begin{array}{r}1.0553 \\
\text { (1 } 0.349)\end{array}$ & $(169.721)$ & $\begin{array}{l}304.9 \\
(29900)\end{array}$ \\
\hline
\end{tabular}




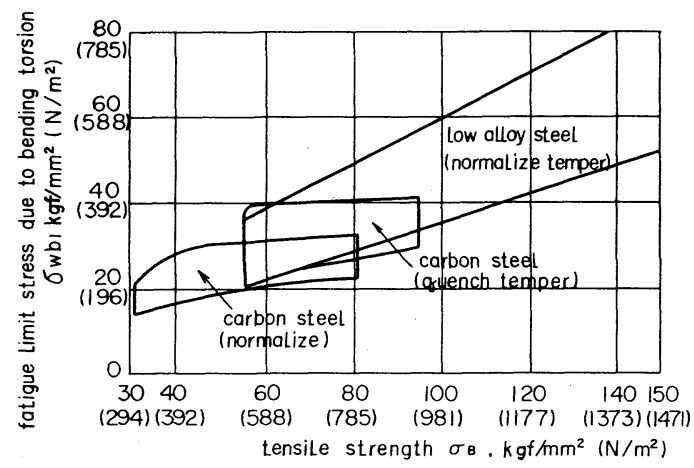

Fig. 11 Relation between fatigue limit stress and tensile strength.

1）水門鉄管技術基準による場合 $\sigma_{a 1}=\sigma_{y} \times \frac{1}{2} \times 0.875=15.31 \mathrm{kgf} / \mathrm{mm}^{2}\left(150 \mathrm{MN} / \mathrm{m}^{2}\right)$

2) 回転曲げ疲労限度を許容応力とした場合 $\sigma_{a 2}=20 \mathrm{kgf} / \mathrm{mm}^{2}\left(196 \mathrm{MN} / \mathrm{m}^{2}\right) \cdots$ Fig. $11^{7)}$ による ローラシャフトの曲げ応力

静的曲げ応力 $\sigma_{b s}=M_{s} / Z=F_{3} \times l / Z$

$$
=1231.4 \mathrm{kgf} / \mathrm{cm}^{2}
$$

(120.76 MN/m²)

動的曲げ応力 $\sigma_{b v}=32.4 \mathrm{kgf} / \mathrm{cm}^{2}$ (Table 6)

(3 $177 \mathrm{kN} / \mathrm{m}^{2}$ )

合計曲げ応力 $\sigma_{b}=1264 \mathrm{~kg} / \mathrm{cm}^{2}\left(123.96 \mathrm{MN} / \mathrm{m}^{2}\right)$ であるので疲労限界を考えた応力でも安全である.

\section{8. 類似ゲート実測值との比較}

本ローラゲートの振動特性と他のバーチカルゲートの 振動実測值とを比較する.

同程度の規模のゲートでも質量 $M$ やばね定数 $K$ との 違いにより振幅・振動数などが異なるので, 単純な数值 の比較では意味がないと考えたが，全体の傾向を把握す るために実測値との比較を Table 9 に示した.

Table 9 Comparison of the experimental data with measured data of existing fixed wheel gate.

\begin{tabular}{|c|c|c|}
\hline & NDF fixed whell gate & Amagase dam orifice gate \\
\hline type & NDF roller gate & roller gate \\
\hline size & $4.100^{W} \times 4.100^{H}$ & $3.590^{\mathrm{W}} \times 4.740^{\mathrm{H}}$ \\
\hline design depth & $24.177^{m}$ & $33.500 \mathrm{~m}$ \\
\hline design force & 392. $406 \mathrm{tf}(\mathrm{KN})(3848.19)$ & $570 \mathrm{tf}(\mathrm{KN}) \quad(5590)$ \\
\hline main girder & 6 & 6 \\
\hline accoleration & $28 \mathrm{gaL} * 1$ & $26 \mathrm{gal} \times 2$ \\
\hline g으 amplitude & $0.018 \mathrm{~mm}$ & $0.001 \mathrm{~mm}$ \\
\hline \$ & $26 \mathrm{gal}$ & $69 \mathrm{gal}$ \\
\hline ¿ & $0.032 \mathrm{~mm}$ & $0.003 \mathrm{~mm}$ \\
\hline \& acceleration & $11 \mathrm{gal}$ & - \\
\hline G. amplitude & $0.013 \mathrm{~mm}$ & $0.024 \mathrm{~mm}$ \\
\hline
\end{tabular}

* 1 Acceleration and amplitude of NDF fixed wheel gate are calculated at the center of No.6 main girder.

2 Values for the orifice gate are measured at the center of the knife edge of the gate lower end when the thrusting mechanism is not working.
屝体の加速度は本ゲートとオリフィス主ゲートでほぼ 同程度であり,振幅は本ゲートの方が大きい傾向にある. これは圧力変動の最大值をとってゲート全面に作用させ たことによるものと考えられる. 圧力変動はゲートリー フの場所によって波形・正力がいくらか異なるので，実 際の圧力変動が作用すれば振幅が小さくなるものと考え られる。

\section{9. 考察}

ダム常用洪水吐設備に用いる流量調節用主ゲートの リーフ面に作用する動水圧を測定し，かつ有限要素法を 用いて静的解析および動的解析を行い，次のような結論 を得た。

（1）ゲートリーフ面に作用する圧力変動は不規則振 動であり, 高水頭・大開度になるに従って変動值が大き くなる.同一条件ではゲートリップ部が最も大きくなり， 扉体の上部になるに従って減少する. ダム水位が HWL $=125 \mathrm{~m}$ の場合, 最大変動圧力はケース 1 で $0.077 \mathrm{kgf} /$ $\mathrm{cm}^{2}\left(7.551 \mathrm{kN} / \mathrm{m}^{2}\right)$, ケース 2 で $0.105 \mathrm{kgf} / \mathrm{cm}^{2}(10.30$ $\left.\mathrm{kN} / \mathrm{m}^{2}\right)$, ケース 3 では $0.109 \mathrm{kgf} / \mathrm{cm}^{2}\left(10.69 \mathrm{kN} / \mathrm{m}^{2}\right)$ であった。これは扉体に作用する最大静水圧 2.4177 $\mathrm{kgf} / \mathrm{cm}^{2}\left(237.1 \mathrm{kN} / \mathrm{m}^{2}\right)$ の $4.5 \%$ に相当する.

（2）扉体の固有振動数を空中および片面接水の条件 で求めた。 ケース 1 および 2 の場合, $1 \sim 3$ 次モードの 振動が剛体振動であり，いずれの場合でも最低振動数は $2.825 \mathrm{~Hz}$ である. 4 次モード以上が弾性体振動であり, 片面接水の条件でケース 1 の場合 $45.28 \mathrm{~Hz}$ ，ケース 2 で $47.13 \mathrm{~Hz}$ である. ケース 3 の場合, 上部フロントロー ラがばね支持となるため 1 ～次モードの振動が剛体振 動で, 5 次モード以上が弾性振動であり，片面接水の条 件で $52.28 \mathrm{~Hz}$ であった。これは本実験より得られた振 動数とオーダー的に合っている.

（3）有限要素法による静的解析の結果, 主析の静的 応力は設計水圧が作用した場合で手計算による応力より も低く，たとえば曲げモーメント等による直応力では $16 \sim 38 \%$ 程度応力が減少している.

一方ローラシャフトの静的応力は, 手計算による応力 と士6 \% 程度のばらつきがあるもののほぼ同じ値となっ ており, 許容応力に十分おさまっている.

（4）模型実験より得られた圧力変動を実物ベースに 変換し, 応答履歴解析を行い, 各節点の変位と加速度の 振幅が発散しないことを検証した．圧力変動による振動 モードはその開度における片面接水の固有振動モードと ほぼ相似であり，ケース 1 で 5 次モード，ケース 2 で 4 次モード, ケース 3 では 4 次モードと 6 次モードの合成 モードとなっている。

（5）主桁の振動による最大たわみはケース 2 の 
No. 6 最下部主桁に発生しており $0.032 \mathrm{~mm}$ であり,こ れは同析の静的たわみ $1.172 \mathrm{~mm}$ の $2.7 \%$ に相当する. 同様に応力ベースで比較すると $2.6 \%$ である.

ローラシャフトの最大動的応力はケース 2 の No. 5 最 下部シャフトに発生しており, $32.4 \mathrm{kgf} / \mathrm{cm}^{2}$ (3 177 $\left.\mathrm{kN} / \mathrm{m}^{2}\right)$ である. これは静的応力の $2.6 \%$ に相当する.

動的応力による疲労強度は応力変動の大きい最下部の 主桁中央部および最下段のローラシャフトについても十 分安全なものである.

（6）水理模型実験と有限要素法を組み合わせて本 ローラゲートの振動特性を調查した．この結果と既設の バーチカルゲートの振動測定結果との比較を行ったが, ほぼ同じ傾向である.

\section{0. あとがき}

この実験に対応する実際の主放流ゲートは大きさにい くらか寸法の変更はあったが, 実物において計測し, 実 験との対応を検討したいと考えている.

最後に, 本研究にあたり多大のご指導ならびに実験の
遂行に終始協力していただいた方々に深く感謝する次第 である.

$$
\text { 参考文献 }
$$

1）荻原国宏・菅原一昌・松山孝弘・一柳直樹：高圧口一 ラーゲートの戸溝と放流水脈に関する研究, 土木学会論 文報告集, 第 333 号, 1983 年 5 月.

2）荻原国宏・菅原一昌・松山孝弘・一柳直樹：ローラー ゲートの新手法とその水理実験, 水門鉄管, No. 127, 1981.5 .

3）荒木正夫・森 正秋：弾性相似を合わせた長径間ゲート 模型の振動実験について, 第 23 回土木学会年次学術講演 会, 1967.

4）内山昭一・木下文雄: 構造解析システム THANKS, 日 本鋼管技報, No. 8, 1979.1.

5）近藤 潔：防撓板の接水振動における付加水質量推定法, 関西造船協会誌，第 177 号, 1980.6 .

6）藤原敏朗・中島 功・林 栄港・大野善雄：天ケ瀬ダム オリフィス主ゲート放流試験, 発電水力, No. 78.

7) 日本材料学会編：金属材料疲労設計便覧, 養賢堂, 1978. (1986.1.8 • 受付) 